\title{
Focusing on the Growth of Entrepreneurship through Interventions and Supports Mechanism: A Case from Bhutan
}

\author{
Müdahaleler ve Destek Mekanizması Yoluyla Girişimciliğin Büyümesine Odaklanmak: Bhutan'dan Bir \\ Örnek
}

\author{
Hemlal BHATTARAI \\ Lecturer \& Dean (RIL), Royal University of Bhutan, \\ Jigme Namgyel Engineering College, BHUTAN \\ b.hemlal@gmail.com \\ https://orcid.org/0000-0002-6512-1685
}

Makale Başvuru Tarihi: 18.06.2021

Makale Kabul Tarihi: 24.08.2021

Makale Türü: Araştırma Makalesi

\begin{abstract}
Anahtar Kelimeler:
Girişimcilik,

Sosyoekonomik

Gelişme,

Amiral Gemisi

Programı,

Girişimcilik

Ekosistemi,

Kuluçka Merkezi,

ÖZET

Girişimcilik, ülkelerin sosyo-ekonomik kalkınmasında çok önemli bir role sahiptir. Girişimlerin ve girişimcilerin ulusal ekonominin önemli bir payına katkı să̆ladığının önemli göstergeleri bulunmaktadır. Girişimcileri, mevcut girişimlerindeki aktif rollerini geri çekmeye zorlayan ve girişim yapmak için tercih edilmeyen yeni seçeneklere yönelten durumsal zorluklar vardır. Bu çalışma, küçük bir ülke olan Bhutan'in son yillarda ülkedeki girişimciliğin büyümesini teşvik etmek için uyguladiğl bir destek mekanizmasının analizini kapsamaktadır. Makalenin haırlanmasında müdahale önlemlerinin altını çizmek için yayınlanmış kaynaklardan elde edilen ikincil verilerden yararlanmaktadır. Çalışma, canlı bir girişimcilik ekosistemi oluşturmak için çeşitli kurumlar ve paydaşlar tarafindan sağlanan inisiyatif ve mekanizmaların çok başarılı olduğunu ortaya çıkarmıştır. Ayrıca Bhutan örneğinde birden fazla kuluçka merkezinin oluşturulması çok başarılı olmuştur. Devam eden pandemi döneminde bile Bhutan, girişimcileri özellikle 'yazlık ve küçük ölçekli sanayileri (CSI)' ekonomisinin kilit unsuru olarak belirlemiştir. Merkezi yönetim, girişimciliği ükenin mevcut beş ylllık kalkınma planında desteklenecek amiral gemisi programlarından birisi olarak önceliklendirmiştir.
\end{abstract}

Keywords:

Entrepreneurship,

Socioeconomic Development,

Flagship Program,

Entrepreneurship Ecosystem,

Incubation Center,

\section{ABSTRACT}

The role of entrepreneurship is always regarded as an important pillar of a country's socio-economic development. There is evidence that startups and entrepreneurs contribute a substantial share of the contribution to the national economy. There are situational challenges encountered by entrepreneurs which make entrepreneurs a not preferred option to venture into as well as forcing existing entrepreneurs to withdraw their active roles. This study makes use of secondary data from the published sources to underline the intervention measures as well as a support mechanism that a small country like Bhutan has been exercising in past decades to foster the growth of entrepreneurship in the country. The study found out the initiative and mechanisms provided by various agencies and stakeholders to make a vibrant entrepreneurship ecosystem proved much successful and also creations of multiple incubation centers are proving out much successful in the case of Bhutan. Even in the era of the ongoing pandemic, Bhutan has identified entrepreneurs especially "cottage and small scales industries (CSI)" as a key element of its economy and prioritizes it as one of the flagship programs to be supported in the current five-year plan of the country. 


\section{INTRODUCTION}

Entrepreneurship plays a vital role in socio-economic development for a region and nation. Social entrepreneurship which through entrepreneurial activities is intended to solve societal issues in a decade has become more of actions as effective as well as sustainable solutions in addressing the persisting social problems (Gawlik, 2015:7-8; Brajević et al., 2014:156). One such study in the case of rural areas in South Africa shows that there are needs for capacity development of women in rural areas so that their performance is due to diverse socioeconomic challenges they are facing (Phungwayo et al., 2014:71-72).

Small and Medium Scale Enterprises (SMEs) happens to play a crucial role when it comes to the overall growth, development and industrialization of economies across the globe. But a country like Nigeria sees below-par performances due to factors within SMEs and other constraints (Ogbo et al., 2012:95-97). The need for developing indigenous entrepreneurs through diverse means of approaches from cradle to grace is felt to competently face the challenges of the $21^{\text {st }}$ century (Ogundele et al., 2005:134).

One of the studies shows that one strong strategy of poverty reduction, growth and economic development programs is a focus on its own business as well as investment environments for entrepreneurship especially in the case of developing countries (Acs et al., 2009:485-486). Universities, governments and companies can play a pivotal role in terms of the growth of new companies as well as capacity enhancement of innovation of the nation through its incubation center (Kipper et al., 2014:947).

There are studies acknowledging entrepreneurship which is certainly the main driver of the socio-economic development of any nation. Similarly, there are concerns about skills development and the support mechanisms are not conducive in many of the underdeveloped and developing countries (Shabbir et al., 2018:1-2). Researchers have also highlighted the need for entrepreneurs which can have significant positive consequences like being a self-reliant country, being independent economically, building the country's image, converting society to productivity, localization and many mores (Khan et al., 2012:2-3).

This research covers the overall strategies that has been devised and implemented in making the entrepreneurial ecosystem a priority in the case of tiny Himalayan country "Bhutan". It also highlighted the contribution from different relevant stakeholders in materializing the actions and initiatives in the domain of entrepreneurship ecosystem that is always rooted and backed by the noble philosophy of 'Gross National Happiness (GNH)' in which Bhutan envisioned its overall approaches.

\section{ENTREPRENEURSHIP IN BHUTAN}

\subsection{Bhutan and Gross National Happiness}

A tiny Himalayan country like Bhutan which is also one of the developing countries has been gearing its priorities for the socio-economic development of the country through its holistic developmental philosophy supported by the concept of 'Gross National Happiness (GNH)'. Ever since the concept of GNH was coined, Bhutan has been instrumental in reinventing its overall philosophy of growth and living through the centric of 'Happiness Index'. The happiness of society thus happens to be the prime thirst in the overall socio-economic development philosophy of Bhutan and it needs to be so always. The essential elements of GNH are as follow: 
Figure 1. Understanding the 4 Pillars of Gross National Happiness

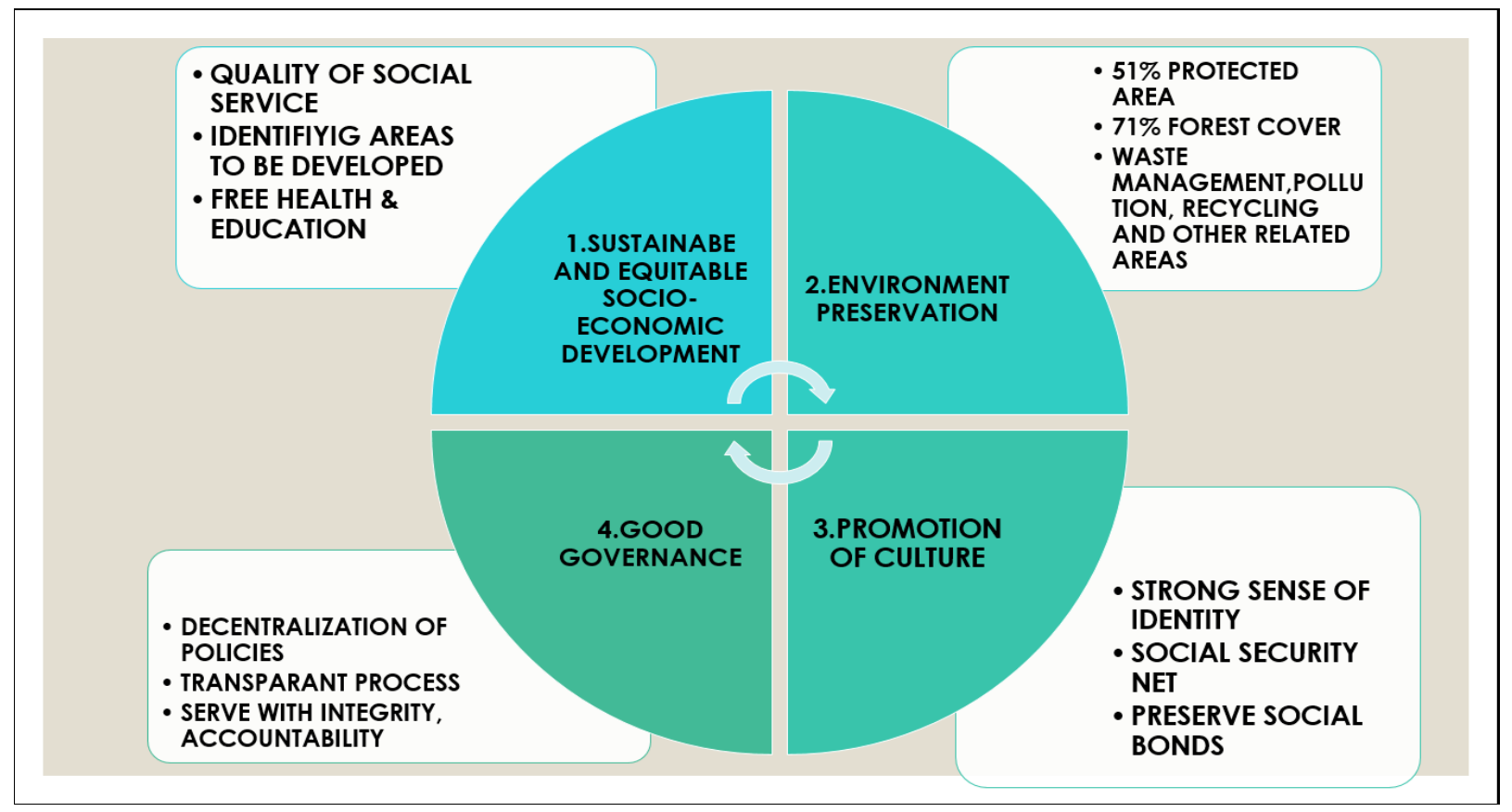

Resource: Adapted from GNHC, RGoB, 2016 (presentation slides)

The four pillars are the building blocks of holistic socioeconomic development approaches which Bhutan has been following for decades. As socio-economic development is the fundamental requirement of any region, the identity that Bhutan placed on this is its model of happiness. Bhutan measures its progress through the happiness indexes which is more important than that of Gross Domestic Product (GDP) where GNH indexes are measured in the case of GDP (Adler, 2009:3-7; Ura, 2012:1-2).

Figure 2. The 9 Domains of Gross National Happiness

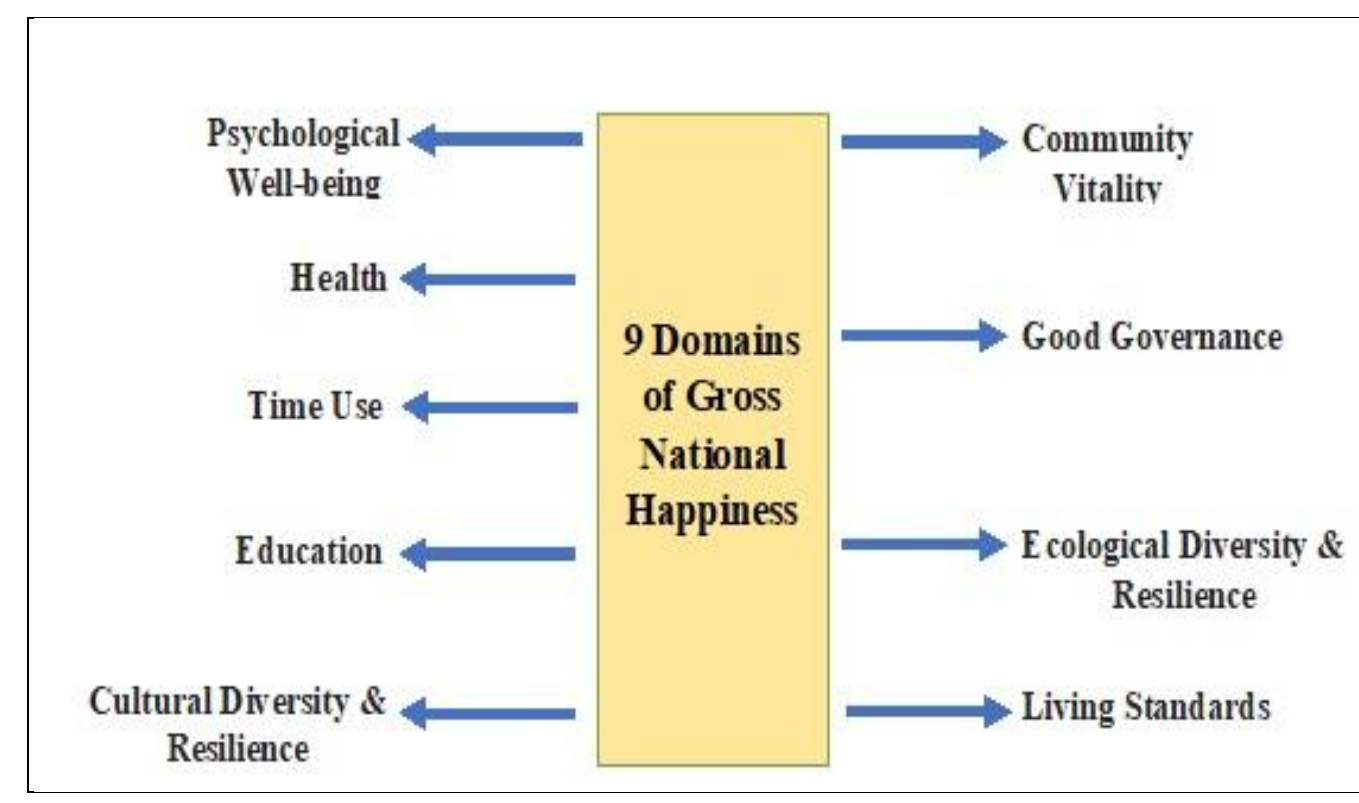

Resource: Prepared by the author (Data incorporated from GNHC, RGoB, 2021).

The four pillars of GNH are supported by critical nine domains as highlighted in the figure above. It is evident from the figure above that multiple inter-related factors are essential in ensuring happiness. These nine domains through supporting indices are building blocks of the pillars of GNH. The domains and the indexes, indicators and variables will ensure that the very objectives are inclusive in whatever we practice, plan and implement and ensure that happiness should always be the priority in our actions. 


\subsection{ENTREPRENEURSHIP ECOSYSTEM IN BHUTAN}

Bhutan has great potential in its entrepreneurial strategies if means of encouragement are made for the consumption of its own indigenous products and work towards limiting or discouraging imports were essential along with supports mechanisms for such indigenous products (Sharma et al., 2020:63). It is a pride for Bhutan where His Majesty the Fifth King of Bhutan during his address to the nation on $109^{\text {th }}$ "National Day Celebration' shared that (DoEHR, MoLHR, RGoB, 2019);

"It is evident that there are many opportunities for entrepreneurship and commercial farming in our country. In addition, our youth are educated, capable, and enthusiastic. If our financial institutions are able to extend unstinted support to young entrepreneurs and farmers, and help in creating numerous opportunities for them, we will derive countless benefits. It will go a long way in strengthening the sovereignty and security of our country, and furthering our social policy of equity and our national objective of self-reliance. If our youth is well educated, and is able to succeed, it will benefit our country as a whole."

In the same report, the perception survey (open and close-ended survey) was conducted by the ministry to about 5000 registered job seekers aimed at understanding overall entrepreneurship awareness, challenges and support, identify complications and gaps assessment.

The need for a very vibrant entrepreneurial ecosystem is essential for any country including Bhutan too. Researchers have highlighted the following needs to ensure a vibrant entrepreneurial ecosystem in Bhutan (Gurung et al., 2018:1).

Figure 3. Various requirements for a vibrant entrepreneurship ecosystem in Bhutan

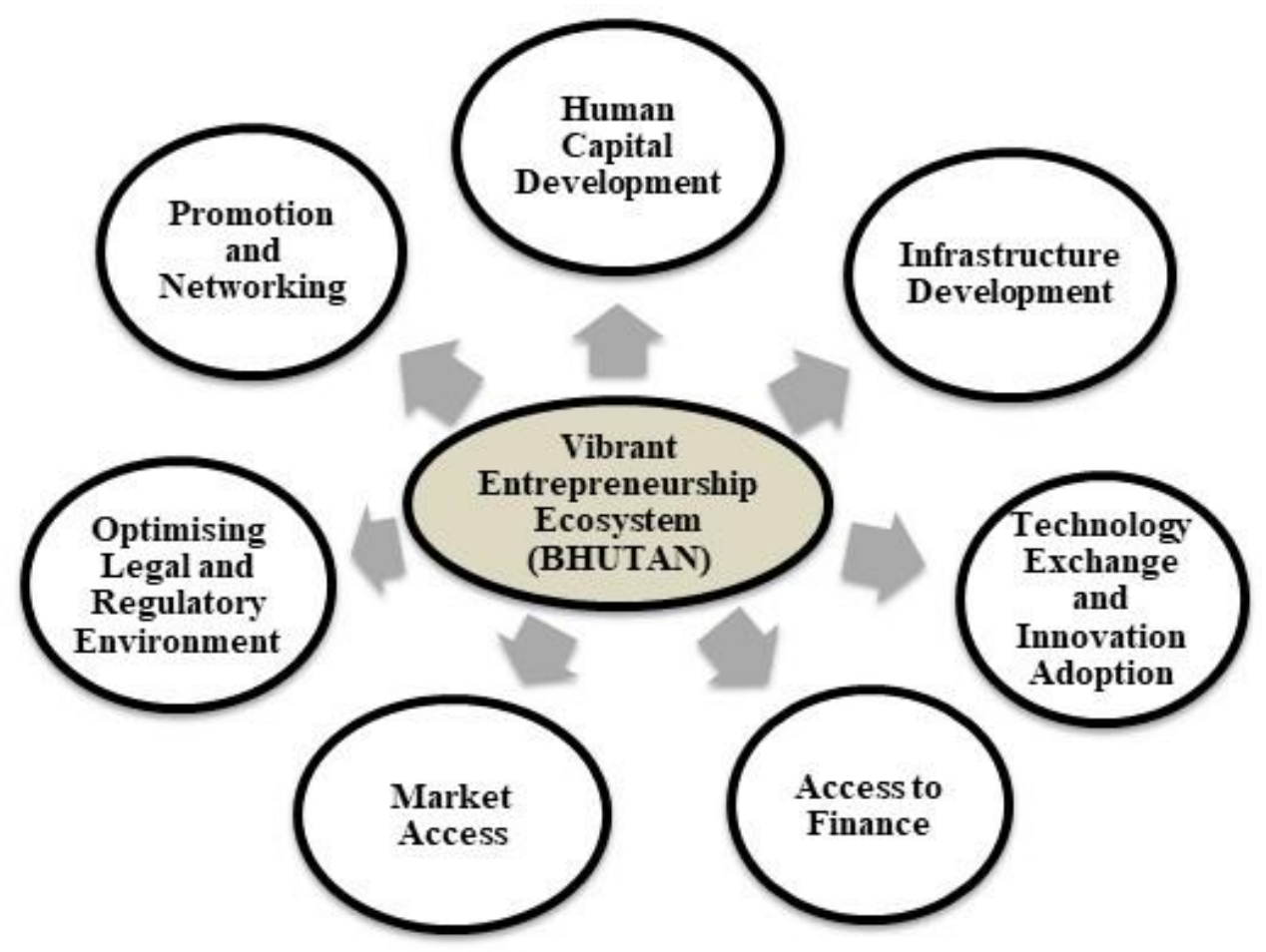

Resource: Prepared by the author (Data incorporated from Gurung et al., 2018)

This demand for multiple organizations and agencies should play an active role along with conducive regulations and policies for fostering the entrepreneurship ecosystem to contribute to the national economy. Some of the promising support service providers as listed below.

Bhutan has come up with a 'CSI Policy 2019' which is accompanied by six strategic domains of focus for the entrepreneurship ecosystem. These policy-level interventions are felt timely for providing conducive platforms for the growth and development of CSIs in the country. These six focus strategic domains include; 
Figure 4. Six strategic domains of focuses from CSI Policy 2019, Bhutan

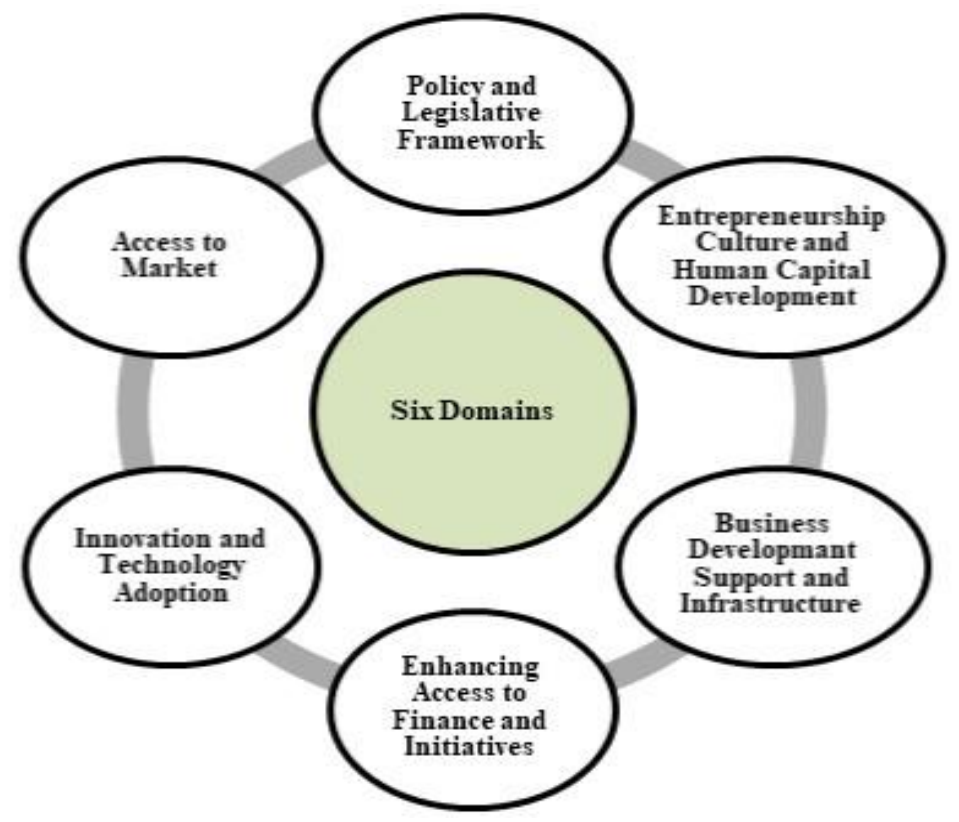

Resource: Prepared by the author (Data incorporated from GNHC, RGoB (CSI Policy 2019)

Information from the figure is evidence of the government's interventions in fostering the growth of CSI in the country by creating a policy framework that can address the niche areas of the entrepreneurship ecosystem. In the same policy document, the government has identified and come up with a series of action points against each of the domains highlighting the proactive roles that the government will play to ensure that all these six domains are strategically materialized.

As support services are felt equally important to have meaningful incorporation of rules and regulations in materializing the growth of the entrepreneurship ecosystem in the country. Bhutan has been proactive in devising measures and platforms with relevant avenues supported which are facilitated through the contribution and coordination of stakeholders/agencies. Such service providers are classified into twelve core groups, and their major services are highlighted as shown in Figures 5 and 6 below.

Figure 5. Entrepreneurship Support Services Providers in Bhutan

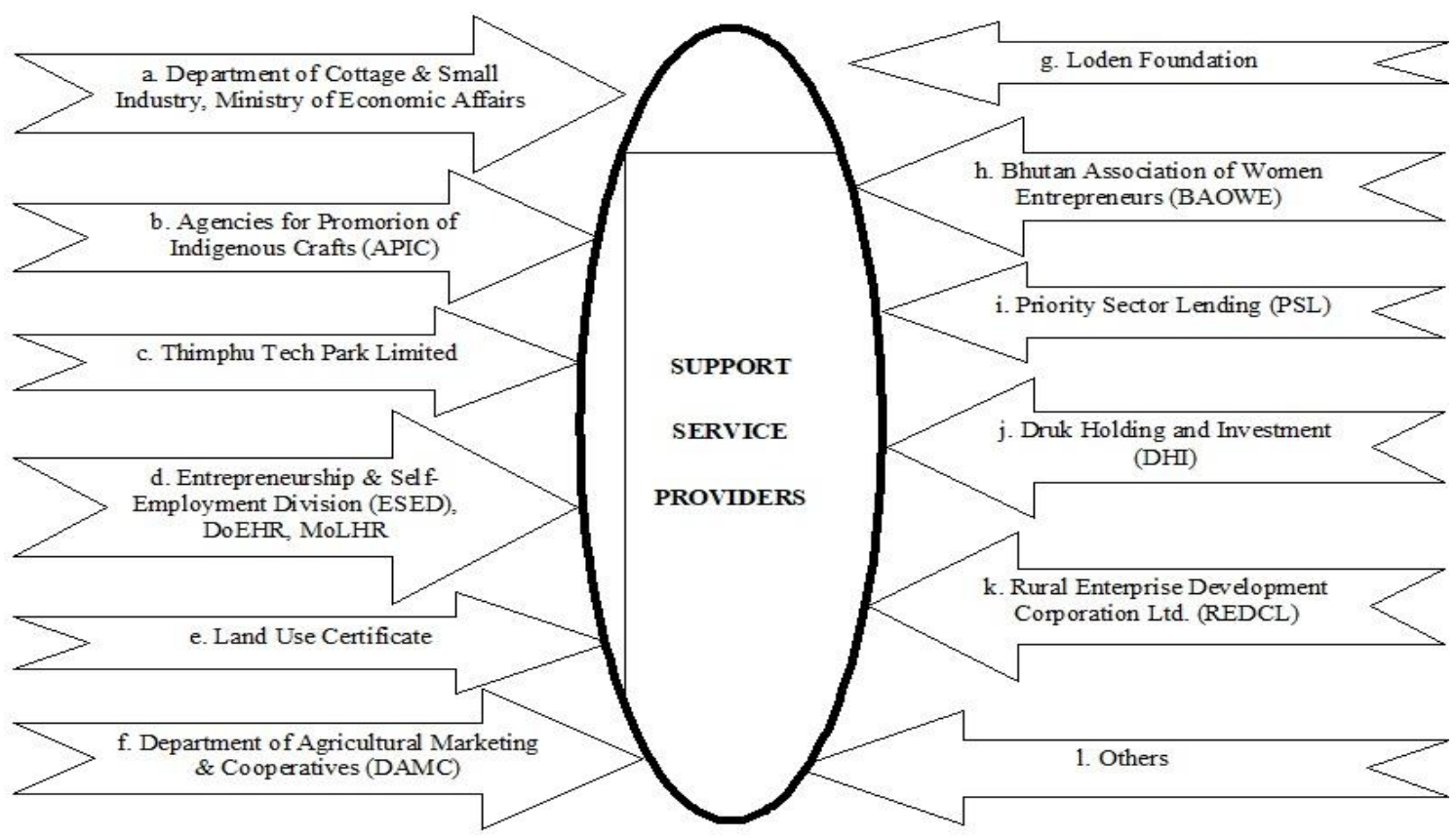

Resource: Prepared by the author (Data incorporated from DoEHR, MoLHR, RGoB, 2019) 
Networks of players need to play their proactive roles to foster and support entrepreneurship which is the crucial backbone of every economy. In the case of Bhutan, the service providers from the government, Civil Society Organization (CSO), Institutions and others as shown in the figures above are agents of support providers.

The role of the above support service providers is to facilitate as well as provide such services which are in need for fostering the growth of entrepreneurship in the countries. These services hence would always prove handy in terms of realistic measures of entrepreneurship's contribution to the national economy.

Figure 6. Entrepreneurship Support Services provided through Support Service Providers in Bhutan

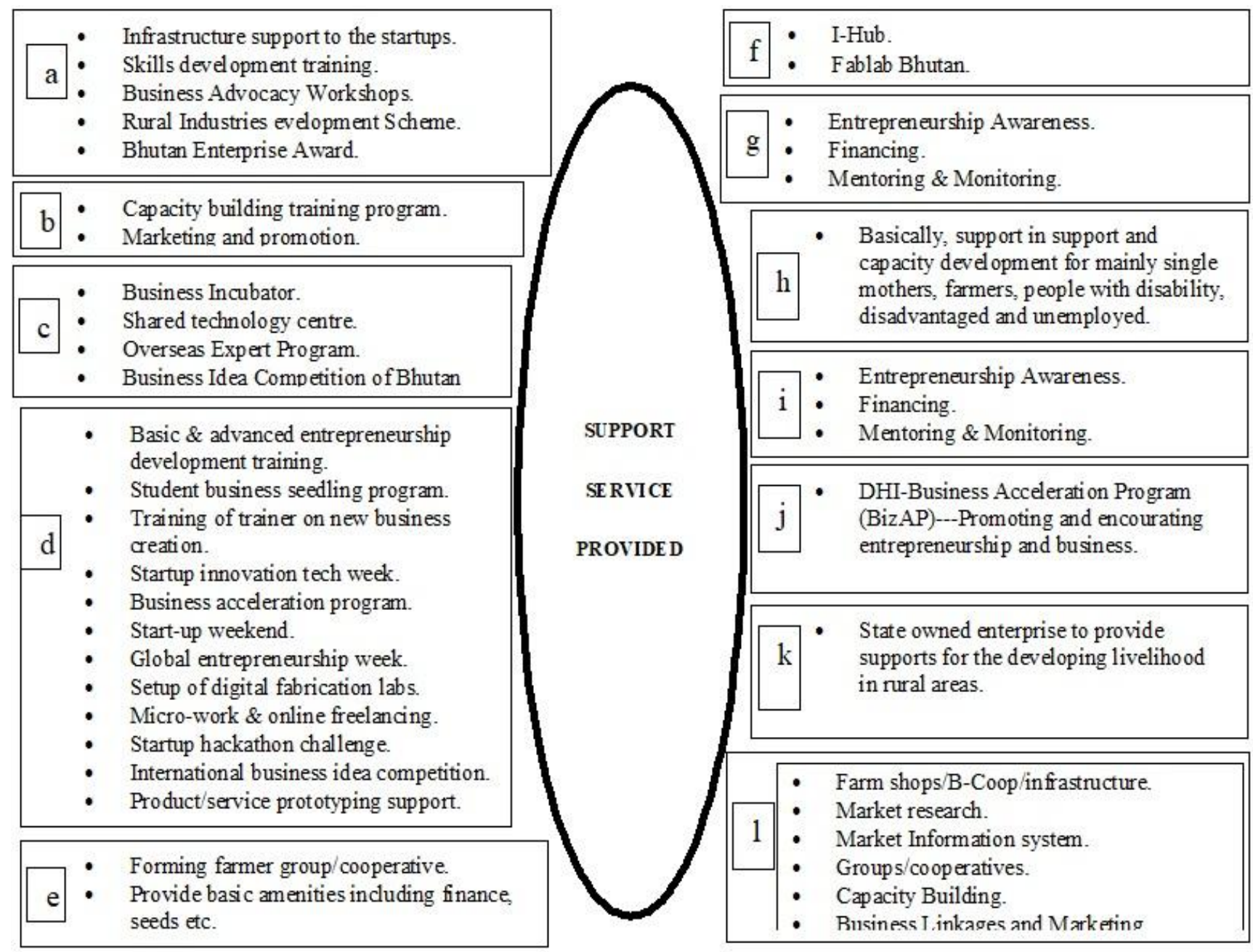

Resource: Prepared by the author (Data incorporated from DoEHR, MoLHR, RGoB, 2019)

The Series of services provided by the service providers in Bhutan are as shown in the figures above where the services range from favorable platform creation, development of amenities and infrastructures, capacity building and enhancement, competitions, financial and mentoring services, market explorations and establishments. Such intervention from the stakeholders as well as relevant agencies will have positive impacts on the enhanced vibrant entrepreneurship ecosystem in the country.

Despite all these provisions for providing services, the findings from the survey reflected that the level of awareness in multiple aspects of critical services was not that promising as shown below. The stastisics as shown in figure below is raounded to nearest percentage in the source literature. Hence there are growing needs felt through this research to facilitate meaningful engagement of relevant stakeholders in creating mass awareness of the support service providers that are available in the country and also to communicate the various services provided by each of these support service providers. 
Figure 7. Level of awareness of entrepreneurship support services and programs

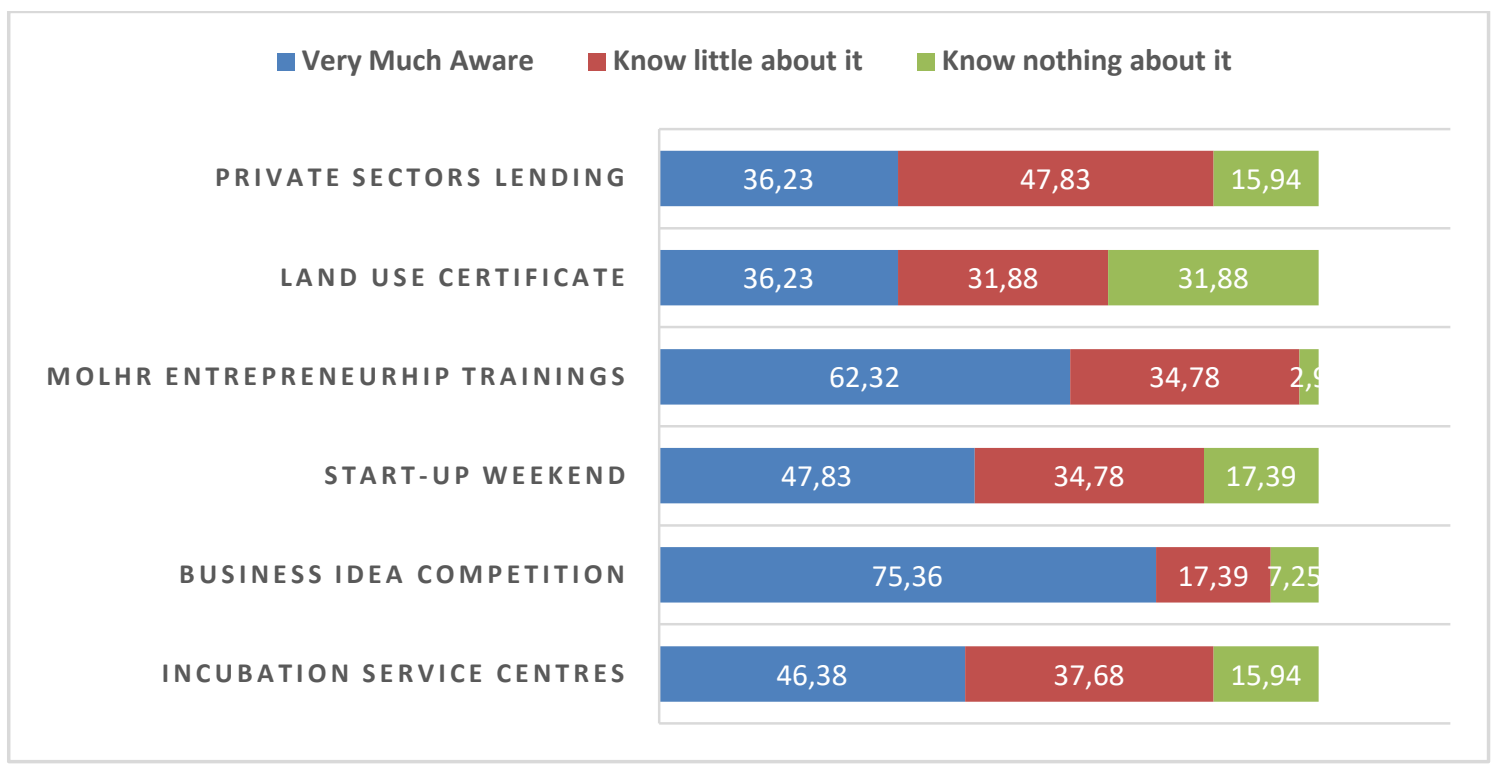

Resource: Prepared by the author (Data incorporated from National HRD Advisory 2019, DoEHR, MoLHR, RGoB).

Report prepared by Scaling Frontier Innovation 2019 shows that Bhutan with its population of 0.798 million and GDP: USD 2.23 bn is ranked high in the domain of ease of doing business and also economic freedom. The ranking for corruption is also the lowest in the region. Despite such conducive policies and regulations, there are multiple support mechanisms that require enhancement (Frontier Incubators, 2019).

In 2020 with a Doing Business (DB) score of 66, Bhutan ranked $89^{\text {th }}$ in ease of doing business whereas New Zealand with a DB score of 86.8 ranked $1^{\text {st }}$ (World Bank, 2020). The score of Bhutan is quite impressive, but it can further be enhanced if factors like awareness and support mechanisms are enhanced. Some hurdles faced in Bhutan by prospective entrepreneurs as researchers found out are i) financial support and ii) infrastructure making new ventures low (Singh, 2020:83).

Furthermore, due to the COVID-19 pandemic that has hit the global economy, the support service providers of Bhutan realized the need to rework their strategies. One of the service providers, the Bhutan Association of Women Entrepreneurs (BAOWE) has come up with its strategic plan 2021-2031 where focuses on women entrepreneurs are prioritized as data from the World Bank analyzed by ILO estimated the percentage of $84.15 \%$ for female vulnerable employment in Bhutan. So, the strategies are to enhance the policies, support mechanisms, preparation for digital societies for enhanced productivity (BAWOE, 2021).

Furthermore, Bhutan has launched Nu. 1.2 billion Cottage and Small-scale Industries (CSI) and startup flagship programme as an important initiative as part of ongoing $12^{\text {th }}$ Five Year Plan (2018-2023) mainly to enhance more of domestic products in replace of imported products creating nearly 2000 jobs opportunities as government initiatives of "Narrowing the Gap" (Bhonsale, 2020:1). The Department of Cottage and Small Industry was initiated in 2010 whose objective is for the development of CSI in Bhutan.

Major shares of industries in case of Bhutan and many countries globally are made up of Cottage, Small and Medium Industry (CSMI) which account for almost $98 \%$ and are a major driver of the economy (GNHC, RGoB, 2021) and it is recorded as 95\% in 2019 in case of Bhutan (Cottage and Small-scale Industry, 2019).

The report also highlighted CSIs as the most suitable factors of the economics due to country geographical and settlement status and thus has been one of the priority flagships programs of RGoB in its $12^{\text {th }}$ Five Year Plan making it an important element of focus. Bhutan has also come up with a revised 'Cottage and Small Industry Policy 2019' in its efforts to promote and develop CSIs seeking it an important element of the Bhutanese economy. As a result, this policy is tagged and prompted towards promoting the establishment of CSIs as well as a support mechanism towards improving the overall performances as well as the competitiveness of the CSIs already in place. The number of CSIs in Bhutan (sector-wise) are as shown in Table 1 below as follow; 
Table 1. The number of CSI in case of Bhutan (2012-2020)

\begin{tabular}{|c|c|c|c|c|}
\hline & Service Sector & P \& M Sector & Contract Sector & Total \\
\hline 2012 (till Dec. 2012) & 8079 & 1329 & 3660 & 13068 \\
\hline 2013 & 7939 & 1287 & 3322 & 12548 \\
\hline $\mathbf{2 0 1 4}$ & 9946 & 1571 & 3676 & 15193 \\
\hline 2016 (Till Dec) & 11550 & 2091 & 3723 & 17364 \\
\hline 2017 (till June) & 13364 & 1669 & 1854 & $16,887(20143)$ \\
\hline 2018 (till 15th June 2018) & 15936 & 2116 & 2143 & 20195 \\
\hline 2019 (till 15th June 2019) & 17553 & 2607 & 1906 & 22066 \\
\hline 2019-2020 & 17387 & 2557 & 1869 & 21813 \\
\hline
\end{tabular}

Resource: Prepared by the author (Data incorporated from DCSI, MoEA, RGoB annual report from 2012-2020)

Though initiatives are always put in place and enhanced, there are a series of challenges being faced so as to make CSI as vibrant and contribute to socio-economic development. Hence in $12^{\text {th }}$ Five Year Plan (FYP) of RGoB has prioritized this and adopted 'Startup and CSI flagship' as one of the flagship programs in the current FYP (2018-2023). This is due to Bhutan's rich and sustainable resources which have prompted the demand for the brand of Bhutan in the global market and moreover, CSI accounts for more than $95 \%$ of the total industry in the country making it as a strong driver of economic growth (Kuensel 2019 and GNHC, RGoB 2020). Furthermore, CSIs contribute significant amounts of jobs, and that is a positive indicator of it.

Table 2. The key components of the Startup \& CSI flagship program of Bhutan

\begin{tabular}{|c|c|c|c|c|}
\hline Target 1 & Target 2 & Target 3 & Target 4 & Target 5 \\
\hline $\begin{array}{c}\text { Value addition for } \\
\text { 21 selected products }\end{array}$ & $\begin{array}{c}\text { Support 746 CSIs } \\
\text { [new/existing] }\end{array}$ & $\begin{array}{c}\text { Impact 3320 } \\
\text { youths }\end{array}$ & $\begin{array}{c}\text { Generate 2000 } \\
\text { employment }\end{array}$ & $\begin{array}{c}\text { Promote 10 CSI products } \\
\text { from import substitution }\end{array}$ \\
\hline
\end{tabular}

Resource: Prepared by the author [Data incorporated from DCSI, MoEA, RGoB (Startup and Cottage \& Small Industry Development Flagship Program 2019-2023)]

The key initiatives as reflected in table 2 above clearly spell out the target impacts ranging from value addition, supports, including youths, generation of employment and product substitution of some import products. Hence, the main target of this flagship program is to provide favorable platforms that play policy and supports roles so that the aspirations of startsup and CSI will be valued for their wider impacts on economic growth.

\section{BUSINESS INCUBATION CENTRE}

\subsection{General understanding of Business Incubation}

While thinking about entrepreneurship and its contributions to the socioeconomic development of a country, the role of a business incubation center becomes crucial. It will provide all-in-one platform support where possible for startups as well as entrepreneurs to work on further directions of their concepts/ideas. Business incubators have grown in popularity as a means of advising, supporting, promoting, and nurturing new business start-ups and entrepreneurs (Gerdsri et al., 2021:1). Business incubation centers are a healthy platform where the creativity, value addition and development of concepts to products or services are germinated before its significant contribution. This center creates a platform to build networks, financial incentives as well as accessibility through networking, capacity development along with evaluating the roles (Li et al., 2020:15).

The same study also realized the important role of the incubation center in terms of needs for its promotion so as to build knowledge-based entrepreneurs for contribution to socio-economic development. There are series of instances where entrepreneurs or aspiring entrepreneurs lack key qualities and capacity which need to be build up at the right time where the business incubation center be the best platform for knowledge as well as a support mechanism.

Business incubation centers can further be enhanced in terms of providing knowledge-based entrepreneurs through the promotion of techno entrepreneurship as well. Researchers have pointed out that there is a need for knowledge-based technology innovation for contribution to socioeconomic development highlighting the greater need to have policy support and another associate program to make it more favorable. Such platforms can provide an avenue to work on scaling up such innovative ideas through technology-enhanced supports and come 
up with commercialization or industrialization settings in order to provide a strong boost of economic growth (Khorsheed et al., 2014:238).

Studies conducted in the past reflected that there are strong linkages between the 'Gross Domestic Product (GDP)' and the number of incubators where the result was analyzed from countries like Asia, Africa, America and Europe showing the influences on GDPs based on the number of incubators.

Setting up of incubation center is essential but on the other hand, the assessment of the incubation center is equally important so as to have a device to evaluate the effectiveness of the budget allocations and any private investment through the development of indicators systems (Tsygankov et al., 2020:1).

The management of the business incubator can use a capacity assessment framework that will provide a deeper insight into strengths and possible improvements so that a better understanding of resources allocation, as well as support measures, can be figured out (Gerdsri et al., 2021:17-18).

Though the incubation center is an agent of changes in terms of creating platforms and support services for startups and entrepreneurs, there is evidence of it not being effective. This situation mostly arises due to a series of challenges they faced including insufficient incubator skills and knowledge, a lack of in-house seed money, a lack of stakeholder support, and a shortage of skilled entrepreneurs and experts (Ndebele et al., 2021:22-23).

\subsection{Business Incubation Centre in Bhutan}

Infusing the culture of entrepreneurship was felt necessary in the education system as a whole in the case of Bhutan. Towards this effort, a Memorandum of Understanding (MoU) was signed between the Department of Employment \& Human Resources under the Ministry of Labor and Human Resources (MoLHR) and Royal Education Council (REC) under the Ministry of Education (MoE) on 9th February 2021 so as to create entrepreneurial mindsets through capacity building of young people while in schools (MoLHR, RGoB, 2021).

Furthermore, the Royal University of Bhutan (RUB) is also equally concerned in providing an entrepreneurial mindset to its graduates through offering Entrepreneurship modules and series of activities. As it is felt that entrepreneurship has become part of education and it cannot be separated. The revised curriculum incorporates entrepreneurial skills and competencies to generate new business ideas, gather economic resources, and establish new business ventures, all of which are necessary to sustain livelihood and support the government's economic development efforts (REC, MoE, RGoB, 2020).

There are already records of some incubation centers in the colleges across the university, and it aims to have incubation centers across university colleges by 2030 as per the strategic plans of the university (RUB, RGoB, 2018). The initiatives as of now have been supported by MoLHR and Loden Foundation to a greater extent and have paved lots of provision in enhancing the entrepreneurship endeavors of colleges under universities. These organizations are also active in providing support measures in schools, training institutes, entrepreneurs as well as relevant organizations.

\section{OBSERVATION AND RESULT}

Bhutan has been successful in identifying the intervention as well as support measures that need to be prioritized so that its socio-economic development can be enhanced in principles of "Gross National Happiness (GNH)". As Bhutan has visualized the potential of CSIs in the contribution to the country's economy, a series of interventions and support mechanisms have been devised and implemented. Based on the record maintained by MoEA, Bhutan the following results were noticed in terms of CSIs in the country since 2012. 
Figure 8. The pattern of different sectors of CSI in case for Bhutan (2012-2020)

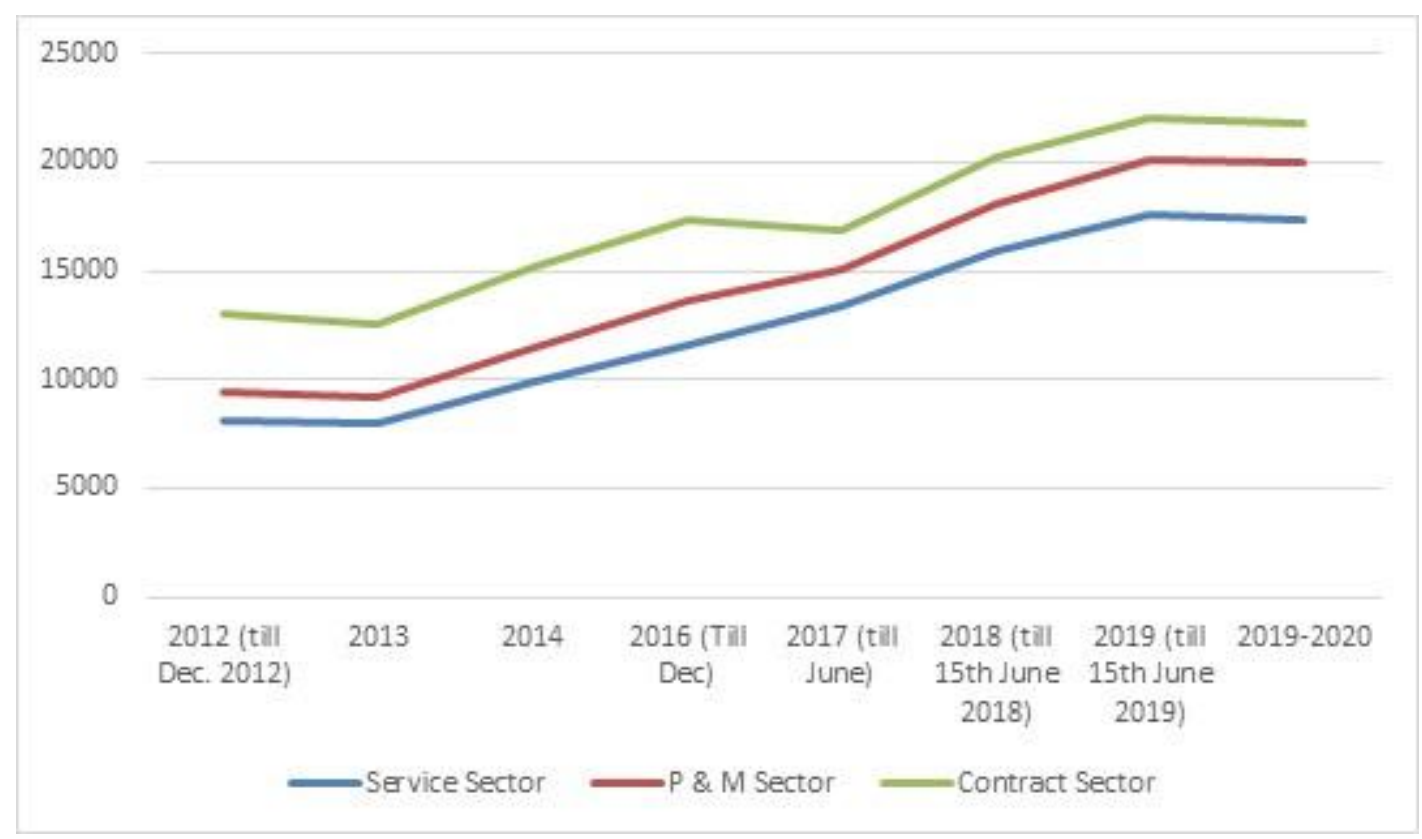

Resource: Prepared by author (Data incorporated from Table 1. (DCSI, MoEA, RGoB 2012-2020))

Results from the key literature from relevant ministry, agencies and stakeholders highlighted that there has been growth in all three sectors of the CSI since 2012 in the case of Bhutan. It is also observed that all three sectors have little fall in 2020 and this may be the result of ongoing impacts due to the pandemic. This reflects the need for further interventions and initiatives along with possible support mechanisms so that the negative falling trend curve can pick up the growth trends in days to come.

The need for understanding the overall entrepreneurial ecosystem and coming up with 'CSI Policy 2019' is one such major initiative of the government along with prioritizing 'startups and CSI flagship' programs in the current pandemic time which has enhanced interventions as well as support in the field of entrepreneurship in recent time. This has created an avenue for providing multiple initiatives and supports including the establishment of need-based business incubation centers in the country which can play pivotal roles in its effective service to budding entrepreneurs, startups as well as existing entrepreneurs. The available referred literature clearly reflects the focus on the entrepreneurial ecosystem as substantial as well as impactful through meaningful interventions and supports in the case of Bhutan.

The limitation of this research is that the result and conclusion are drawn from the appropriate literature that has been published or recorded in the form of a report, paper, or website information. Further understanding of other associated supports and needs from the perspective of entrepreneurs or aspiring entrepreneurs can be studied so that more realistic insights can be achieved in a long run. As it has a chain of associations and linkages to materialize the versatile entrepreneurship ecosystem, a thorough need-based analysis in case-by-case situations can be implemented at a continuous-time.

\section{CONCLUSION}

Entrepreneurship contribution to the socio-economic development of the country is prominent. In the case of Bhutan, it has placed greater importance in nurturing the existing entrepreneurs as well as creating a favorable platform for budding entrepreneurs and startups. Bhutan has highly regarded the contributions in its economy by the CSIs where the government and other relevant organizations/agencies/stakeholders come together to provide conducive platforms in terms of creating a vibrant entrepreneurship ecosystem in the country.

This study has noticed that Bhutan is one of the tiny Himalayan countries which is still regarded as one of the 'Least Development Countries (LDC)' has been proactive in fostering entrepreneurship through progressive actions in enhancing the interventions where necessary along with vital support mechanisms. One of the promising developments and approaches that are visible despite the major setback in its economic development 
as well as social welfare due to the pandemic is the noble initiatives of critical flagship programs by the government during the current five-year plan (2018-2023) of Bhutan.

The 'Startups and CSI flagship' program is one of the flagship programs identified and given the priorities. As a result, the relevant organizations/agencies/stakeholders are entrusted with added responsibilities as well as accountability to materialize these initiatives through diverse initiatives as well as a support mechanism that will boost the growth and development of startups and CSI which in return will have positive contributions to country socioeconomic development that are in line with the principles of Gross National Happiness (GNH).

This has been observed in terms of enhancing the academic approaches through development as well as the implementation of the curricula in schools/institutions, supporting and enhancing the capacity development supports, providing rightful access to information and markets, creating feasibility of meaningful access to finances, providing platforms through establishment and enhancements of incubation centers, building creativity as well as innovative culture and its promotions through ideas competitions and supports. This is progress that Bhutan has been successful despite multiple challenges. It should always strive to further enhance its creative and innovative initiatives as well as support mechanism so that entrepreneurship is seen as a prospective future by its people and it will enhance the socio-economic development of a country.

\section{REFERENCES}

ACS, Zoltan J. and NICOLA, Virgill (2010), "Entrepreneurship in Developing Countries", Handbook of Entrepreneurship Research, S.6, pp.485-515.

ADLER, Alejandro (2009), "Gross National Happiness in Bhutan: A Living Example of an Alternative Approach to Progress", Social Impact Research Experience Journal (SIRE), pp.1-139, University of Pennsylvania, https://repository.upenn.edu/cgi/viewcontent.cgi?article $=1003 \&$ context $=$ sire (Date of Access: 03.08.2010).

BAOWE (2021), "Bhutan Association of Women Entrepreneurs- Strategic Plan 2021 - 2031", Bhutan Association of Women Entrepreneurs (E-Book), www.baowe.org/wpcontent/uploads/2021/03/BAOWE-Strategic-Plan-2021-2031-1.pdf (Date of Access: 03.08.2010).

BHONSALE, Mihir (2020), "Bhutan: Nurturing the Entrepreneurship Ecosystem", ORF, 20 May 2020, www.orfonline.org/research/bhutan-nurturing-entrepreneurship-ecosystem-66306/ (Date of Access: 03.08.2010).

BRAJEVIĆ, Slađana, ANTONIJA, Babić and IVONA, Jukić (2015), "Social Entrepreneurship and Economic Development", Entrepreneurship, pp.156-166.

DCSI, MoEA, RGoB (2012-2020), "Annual Report (2012-2020)", Ministry of Economic Affairs (E-Book), www.moea.gov.bt/?page_id=943 (Date of Access: 03.08.2010).

DoEHR, MoLHR, RGoB (2019), "An Assessment of Entrepreneurship Support Services", National HRD Advisory 2019: The Human Resource and Skills Development Division (HRSDD), Department of Employment and Human Resource (DoEHR), MoLHR Publisher, Bhutan, www.molhr.gov.bt/molhr/wp-content/uploads/2019/06/5th-NHRD-Advisory-2019.pdf (Date of Access: 03.08.2010).

FRONTIER, Incubators (2019), "Mapping and Analysis of Entrepreneurial Ecosystems Incubators and Accelerators in the Asia-Pacific", Entrepreneruial Ecosystem Mapping Report 2019 (E-Book), scalingfrontierinnovation.org/wp-content/uploads/2020/03/8_Frontier-Incubators_EntrepreneruialEcosystem-Mapping-Report-2019.pdf (Date of Access: 03.08.2010).

GAWLIK, Remigiusz (2015), "Editorial: Social Entrepreneurship and Socio-Economic Development", Entrepreneurial Business and Economics Review, S.3(1), pp.7-8.

GERDSRI, Nathasit, LEWWONGCHAROEN, Boonkiart, RAJCHAMAHA, Kittichai, MANOTUNGVORAPUN, Nisit, PONGTHANAISAWAN, Jakapong and WITTHAYAWEERASAK, Watcharin (2021), "Capability Assessment toward Sustainable Development of Business Incubators: Framework and Experience Sharing”, Sustainability, S.13(9), pp.1-20.

GNHC, MoEA, RGoB (2020), "Startup and Cottage \& Small Industry Development Flagship Program 20192023", Ministry of Economic Affairs (E-Article), https://flagship.gnhc.gov.bt/wp- 
BHATTARAI, Hemlal - Focussing on the Growth of Entrepreneurship through Interventions and Supports Mechanism: A Case from Bhutan content/uploads/2020/05/Startup-CSI-Blueprint-2019_Shared-5-Feb-2020.pdf (Date of Access: 03.08.2010).

GNHC, RGoB (2016), GNHC Presentation - GNH Centre Bhutan, GNH Centre Bhutan, Bhutan, http://www.gnhcentrebhutan.org/wp-content/uploads/2016/03/GNH-PresentationGNH-Centre-Bhutan.pdf (Date of Access: 03.08.2010).

GNHC, RGoB (2021), 4 Pillars and 9 DOMAINS OF GNH - GNH Centre Bhutan, GNH Centre Bhutan, Bhutan, www.gnhcentrebhutan.org (Date of Access: 03.08.2010).

GURUNG, Ram Bahadur and TENZIN, Jigme (2018), "The Entrepreneurship Culture", The Druk Journal (EArticle), drukjournal.bt/the-entrepreneurship-culture/ (Date of Access: 03.08.2010).

KHAN, Shad Ahmad, SHARMA, Kavita, BANERJEE, Aditya ve SINGH, Wahengbam Jotin (2012), "Analysis of a SEZ establishment in Bhutan as a Potential Solution for the Promotion/Growth of MSMEs and Role of Micro Finance in Making it Effective", Conference (E-Article), pp.1-16, www.rtc.bt/Conference/2012_10_15/5-ShadKhan-SEZs_SMEs.pdf (Date of Access: 03.08.2010).

KHORSHEED, Mohammad S, AL-FAWZAN, Mohammad and AL-HARGAN, Abdulaziz (2014), "Promoting Techno-Entrepreneurship through Incubation: An Overview at BADIR Program for Technology Incubators", Innovation, S.16(2), pp.238-249.

KIPPER, Liane Mahlmann, RODRIGUES, Evandro, FERRARI, Aline Graziele ve MARIANI, Bruna Bueno (2018), "Universities and Incubators: Key Factors Driving Entrepreneurship and Socioeconomic Development", Independent Journal of Management \& Production, S.5(4), pp.947-965.

LI, Cai, AHMED, Naveed, QALATI, Sikandar Ali, KHAN, Asadullah and NAZ, Shumaile (2020), "Role of Business Incubators as a Tool for Entrepreneurship Development: The Mediating and Moderating Role of Business Start-Up and Government Regulations", Sustainability, S.12(5), pp.1-23.

MoEA, RGoB (2012), "Cottage, Small and Medium Industry Policy of the Kingdom of Bhutan", Ministry of Economic Affairs (E-Book), www.gnhc.gov.bt/en/wp-content/uploads/2017/05/CSMI-Policy-2012.pdf (Date of Access: 03.08.2010).

MoEA, RGoB (2019), "Cottage and Small Industry Policy 2019", Ministry of Economic Affairs (E-Article), www.gnhc.gov.bt/en/wp-content/uploads/2019/07/CSI-Inside-Final.pdf (Date of Access: 03.08.2010).

MoLHR, RGoB (2021), "MoU on Integration of Entrepreneurship in School Education", Ministry of Labour and Human Resources (E-Article), https://www.molhr.gov.bt/molhr/?p=42450 (Date of Access: 03.08.2010).

NDEBELE, Ntombifikile ve CHINJOVA, Fainos (2021), "Effectiveness of Incubation Centres in Creating Sustainable Businesses in Zimbabwe", South Asian Research Journal of Agriculture and Fisheries, S.3(2), pp, 17-25.

OGBO, Ann and AGU CHIDIEBERE, Nwachuhwu (2012), "The Role of Entrepreneurship in Economic Development: The Nigerian Perspective", European Journal of Business and Management, S.4(8), pp.95-106.

OGUNDELE, Ogundeji Jolasinmi Kayode and JAMES, O. Abiola (2005), "Entrepreneurship and National Development: A Proposal for Evangelistic Agenda", European Scientific Journal, S.8(6), pp.134-148.

PHUNGWAYO, Louis Gabangani and TEBOGO, Mogashoa (2014), "The Role of Entrepreneurship on the Socio-Economic Development of Rural Women: A Case Study of Kwa-Mhlanga in the Mpumalanga Province (Republic of South Africa", International Journal of Business and Social Science, S.5(9), pp.71-77.

REC, MoE, RGoB (2020), "New Normal Curriculum Framework for Business and Entrepreneurship, Classes XI-XII", Ministry of Education, Royal Education Council, Bhutan, https://rec.gov.bt/download/56/curriculum-framework/4779/business-entrepreneurship-nncframework.pdf (Date of Access: 03.08.2010).

RINZIN, Yangchen C. (2019), "Startup and CSI Development Flagship to Help Youth", Kuensel Online (EArticle), https://kuenselonline.com/startup-and-csi-development-flagship-to-help-youth/ (Date of Access: 03.08.2010). 
RUB (2018), Strategic Plab 2018-2030, Royal University of Bhutan, Bhutan, https://www.rub.edu.bt/images/rub/Key-Documents/Strategic-Plan/Strategic-Plan-2018-to-2030.pdf (Date of Access: 03.08.2010).

SHABBIR, Muhammad Salman, SHARIFF, Mohd Noor Mohd, ALSHAIBANI, Yasameen Hamzah, FAISAL, Muhammad and SALMAN, Rabia (2018), "Entrepreneurship and Skills Development for Socioeconomic Growth; Present Landscape and Future Agenda for Pakistan", Academy of Entrepreneurship Journal, S.24(3), pp.1-12.

SHARMA, Dhanapati and GAUTAM, Khem Prasad (2020), "Challenges and Prospects of Entrepreneurship in Bhutan from the Lens of Business Educators", Journal of Economics, Management and Trade, S.26(9), pp.63-71.

SINGH, Elangbam Haridev, WANGDA, Sonam, KHAN, Sadaf ve KHAN, Shad Ahmad (2020), "Exploring the Obstacles for Start-ups in Bhutan: From a Prevented Entrepreneurs Perspective", International Journal of Innovation, S.11(4), pp.70-87.

TSYGANKOV, Nikita S., PETRUNINA, A. Elena, MOSKALEV, Alexander K. and VALKOVA, Y. E. (2020), "Business Incubator Assessment Model", IOP Conference Series: Materials Science and Engineering, S.986, pp.1-14.

URA, Karma, ALKIRE, Sabina and ZANGMO, Tshoki (2012), Bhutan: Gross National Happiness and the GNH index, pp. 1-65, Ophi Publisher, Bhutan, https://www.ophi.org.uk/wp-content/uploads/Ura-et-alBhutan-Happiness-Chapter.pdf (Date of Access: 03.08.2010).

WORLD BANK (2020), Doing Business 2020, World Bank Group Publisher, Washington, https://documents1.worldbank.org/curated/en/688761571934946384/pdf/Doing-Business-2020-

Comparing-Business-Regulation-in-190-Economies.pdf (Date of Access: 03.08.2010). 